\title{
GESNERIACEAE OF THE OLD WORLD II. A new Didymocarpus from Sumatra
}

\author{
B. L. BURTT
}

\begin{abstract}
Didymocarpus koerperi B. L. Burtt is described from near Pajakumbuh, central Sumatra. It belongs to a group of species that is chiefly distinguished by having a single nectarial gland lying below the ovary, instead of the usual cupular disc.
\end{abstract}

The new species of Didymocarpus here described was collected by Dr Hans Koerper, in the Harau canyon, near Pajakumbuh in central Sumatra, and was sent by him to the Munich Botanical Garden. There it came under the care of Mr J. Bogner who, knowing of my interest in Gesneriaceae, very kindly made material available to me.

Didymocarpus koerperi belongs to an extremely interesting group of species which range from southern Thailand to Borneo with species on the Malay Peninsula and in Sumatra, but it is absent from Java. Described Peninsular species in the same alliance are D. flavobrunneus Ridley, D. pyroliflorus Ridley and D. falcatus Kiew; on Borneo there is $D$. beccarii C. B. Clarke, which is now known from a number of stations in Sarawak and from localities in Kalimantan near the Sarawak border. But in all areas within the range of the group there are unnamed species to be investigated. These are under study by Prof. A. Weber (University of Vienna) and myself; but that work will not be finished quickly. It therefore seems desirable to publish the description of $\mathrm{Dr}$ Koerper's plant in advance of the rest of the study as the plant is already in cultivation, at least in his own fine greenhouses, and in the Botanical Gardens at Munich, Vienna University, and Edinburgh. It is an attractive little plant with distinctive silky leaves and white flowers tinged to pink. It will certainly be passed around from one garden to another and therefore needs a name. It is a pleasure to associate it permanently with Dr Koerper who introduced it into cultivation and who invited me to see it, and many other good plants, in his collection at Geretsried.

Dr Koerper was not, however, the first to collect this species. So far as I know the first specimens were found by the late A. H. G. Alston of the British Museum in 1954, and in the next year it was collected again by Dr W. Meijer, and another year later by the late Dr M. Jacobs. All three collections were from the same general area, around Pajakumbuh.

When Dr Koerper revisited the locality he was surprised to find another Didymocarpus growing in soil at the foot of the rocks carrying $D$. koerperi. This was a caulescent plant $30 \mathrm{~cm}$ high, with smaller elliptic leaves and peduncles barely exceeding the leaves, and with larger fruits (up to $4 \mathrm{~cm}$ long; not only $2 \mathrm{~cm}$ as in D. koerperi). Unfortunately material sent to Edinburgh did not survive and we have failed to raise it from the few seeds available. It is not unknown in Gesneriaceae for plants growing on rocks and those on the forest floor to look very different. Hexatheca fulva and Cyrtandra farinosa both form small leaf-fans, with almost no internodes, when growing on cliff-faces, but in soil at the base of the cliff they will develop an erect stem 


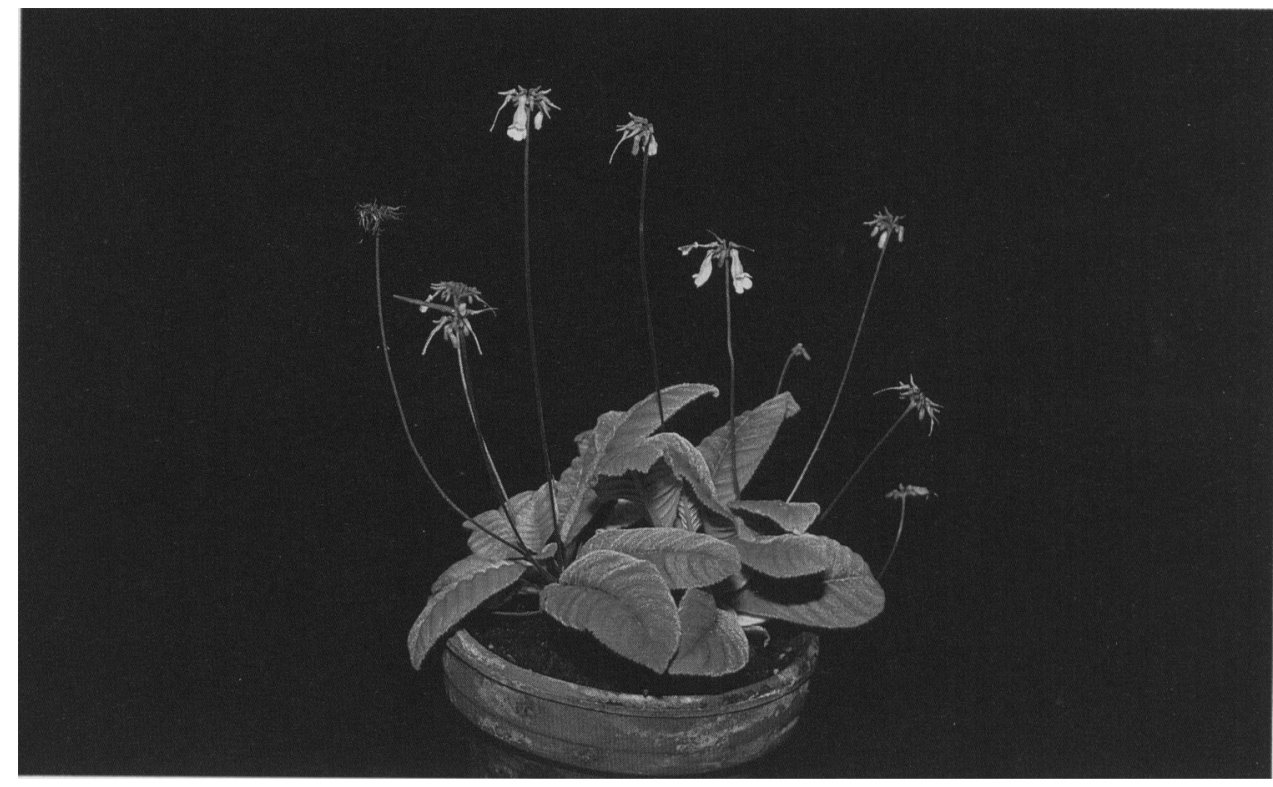

Plate 1. Didymocarpus koerperi. Photo A. Weber.

with internodes and decussate leaves. Whether Didymocarpus koerperi can behave in the same way must remain uncertain until flowers of the erect plant are available for study.

Didymocarpus koerperi B. L. Burtt, species nova inter species hactenus e Sumatra descriptas tantum $D$. corniculato Jack (speciei male cognitae) ob folia alterna et flores capitatos affinis, sed ab hac foliis oblongo-ellipticis (nec obovatis, acuminatis) facile distinguiter. Fortasse D. falcato Kiew e peninsula Malayana proxime accedit, sed habitu humiliore (caule haud ad $1 \mathrm{~m}$ attingente), foliis bullatis oblongo-ellipticis (nec planis ellipticis utrinque angustatis), corolla extra papillis conicis minutis acutis rubris pubescente (nec pilis minutis glandulosis obsita) recedit.

Plant rosulate. Leaves alternate; petiole up to $5 \mathrm{~cm}$ long, densely appressed-pilose; lamina 5-12 $\times 2-4 \mathrm{~cm}$, oblong-elliptic, apex acute to obtuse, base abruptly narrowed, margin finely serrate; veins in 12-15 (sub)opposite pairs, i̇tercostae raised and giving the leaves a bullate appearance; upper surface sericeous with rather long, multicellular, loosely appressed hairs; underside with appressed hairs on midrib and side veins, and very scattered short hairs on some veinlets, glabrous between the veins but with dense stomatal turrets (appearing as white dots under a lens). Peduncles axillary, solitary, up to $23 \mathrm{~cm}$ long and much exceeding the subtending leaves, beset with short pointed spreading hairs; bracts $2 \mathrm{~mm}$ long, hairy. Cyme many-flowered, condensed into a head. Pedicel 2-3mm, shortly hairy, becoming thicker and 3-5mm in fruit. Sepals 5, 1.5$2 \mathrm{~mm}$ long, narrowly triangular, shortly hairy. Corolla white, appearing pink in the upper part from the indumentum of short red hairs, and sometimes also flushed 
mauve-pink on upper side; tube $9.5 \mathrm{~mm}$ long to dorsal sinus, $10.5 \mathrm{~mm}$ to lateral sinus, inflated and bulb-like at the base, contracted at $2-2.5 \mathrm{~mm}$ above the base, then broadening upwards; lobes all rounded at tips and subequal, c. $3.5 \times 3.5 \mathrm{~mm}$, the upper $4 \times 5 \mathrm{~mm}$, all shortly hairy inside. Stamens 2 ; filaments arising $4 \mathrm{~mm}$ above base of corolla, $4.5 \mathrm{~mm}$ long, glabrous, thickest in the middle; anthers pale buff-yellow, $1.75 \mathrm{~mm}$ across the widely divergent thecae, coherent, connective thick, discoid, with minute free tooth pointing forwards. Nectary-disc unilateral, below the ovary, $1.5 \mathrm{~mm}$ long, entire at tip. Ovary cylindrical; minutely hairy, c. $3 \mathrm{~mm}$ long; style $7.5 \mathrm{~mm}$, minutely hairy; stigma capitate, $0.5 \mathrm{~mm}$ diam., very shallowly bilobed. Capsule $\mathrm{c} .1 .8 \mathrm{~cm}$ long, opening on the upper side, c. 20 in a head; seeds barely $0.5 \mathrm{~mm}$ long, \pm elliptic, lightly longitudinally ridged with a row of depressions between the ridges.

Type: Sumatra, Pajakumbuh, Harau valley, c. $800 \mathrm{~m}, H$. Koerper, cultivated plant (holo. E; iso. M, WU).

SUMATRA. West coast, Air Putih, E of Pajakumbuh, 520m, 22 ii 1954, Alston 13796 (BM); Harau canyon, Pajakumbuh, c.600m, iii 1955, Meijer 3082 (BM, L); Pajakumbuh, c. $0^{\circ} 10^{\prime} \mathrm{S}, 100^{\circ} 40^{\prime} \mathrm{E}, 15$ viii 1956, Jacobs 4611 (L).

\section{Note Added In Proof}

Since this paper was sent to press I have visited the Herbarium Bogoriense in Java. There I found additional material of this species, including the earliest record of its collection. The specimens are:

SUMATRA. West coast, Fort de Koch, v 1927, Yates 2495; Pajakumbuh, Harau Kloof, 21 viii 1932, Kleinhoonte 492; ibidem, 600m, 27 viii 1983, Hotta \& Tamin 334. 